\title{
ANALYSIS OF THE ATTITUDES OF CZECH ENTREPRENEURS ON ISSUES OF ELECTRIC VEHICLES' UTILIZATION IN MORAVIAN-SILESIAN REGION
}

\author{
Eva Chlebišová, Jana Kyzeková
}

\section{Klíčová slova:}

životní prostředí, marketing inovací, elektrická vozidla, green marketing, nákup organizací, marketingová komunikace

\section{Key words:}

environment, marketing of innovations, electric vehicles, green marketing, organisational buying, marketing communications

\begin{abstract}
Abstrakt
Současný automobilový průmysl prochází rychlým růstem a nárůst počtu vozidel produkujících výfukové plyny se projevuje ve vzrůstajícím znečištění městských center. Jednou z možností jak zabránit dalšímu znečištování prostředí, je využití vozidel s elektrickým pohonem, které samy o sobě nejsou zdrojem výfukových plynů a hluku. Díky vyspělým technologiím dnes elektrické automobily dosahují podobných parametrů užitnosti jako běžné automobily se spalovacími motory. V tomto článku se zabýváme možnostmi a omezeními využití elektrických vozidel pro podnikatelské účely a postoji jejich zástupců $\mathrm{k}$ problematice elektromobility. Vstupní data analýzy byla získána $\mathrm{v}$ rámci studie prováděné $\mathrm{v}$ roce 2010 v Moravskoslezském kraji.
\end{abstract}

\begin{abstract}
Current automobile industry is coming through the fast rise and the growing amount of vehicles producing exhaust gases is increasing pollution in city centres. One possibility to protect the urban environment is to use vehicles with electric engines, which do not emit pollution and noise. Thanks to modern sophisticated technologies current electric vehicles are comparable with common vehicles with combustion engines. In this paper, we discuss possibilities and limitations of diffusion and utilization of the electric vehicles and attitudes of entrepreneurs to the usage of electric vehicles for company purposes. The input data were gained during the study held in 2010 in Moravian-Silesian Region.
\end{abstract}

\section{Introduction}

Current studies demonstrate the automobile exhaust gases and emissions are significant sources of pollution in big cities; the estimated share of these gases on total pollutants in cities is $65 \%$ (Xinlian, 2009). Although governmental activities of many countries aim for progressive elimination of negative impacts on environment in cities, the statistic shows the amount of vehicles on the Earth will exceed 3 billion vehicles till the year 2050 (Gärling and Thøgersen, 2001), and only in China the amount will increase to 150 million automobiles consuming 250 million tons of gasoline annually (Xinlian, 2009). Although these problems have been discussed in western countries for more than 30 years, in the Czech Republic we can observe a significant shift to the sustainable gasoline consumption and pollution in past 15 years. Although the current policy of nations enforces environmentally friendly technologies, the necessity of independent mobility and travel demand are still contrasting with changing requirements on sustainable economy development and environmental conditions. Nowadays it seems to be very important to exploit all possibilities of alternative 
vehicles and energy sources to ensure sustainable city traffic, minimize the pollution, and also impacts of polluted environment on the health of inhabitants. However, these new technologies still need effective marketing activities to become acceptable for customers. Therefore our research is focused on issues of electric vehicles diffusion, and attitudes of organisational buyers to electric vehicles' utilization.

\section{Benefits of Electric Vehicles}

The idea of the electric vehicle (EV) is not new. The rise of electric vehicles started with the first electric trams, as a new type of mass transport vehicle. The inhabitants' experience with relatively faster type of transportation revealed a new need for mobility supported by the development of a car with an internal consumption engine in 1889 (Windrum, 2009). In Europe, internal combustion vehicle (ICV) became a dominant type of urban vehicle after the Second World War. This evolution process lead to the mass city automobile transportation. In the 30s, EVs were widely used, but the main problems of their utilization were insufficient capacity of lead batteries and engine controlling. Further rapid development of EVs started after the invention of semiconductor, and was supported by the environmental policy of the USA. Although the modern development of EVs is strictly connected with investments to the environment, EVs can provide more customer benefits. Current research and sophisticated methods enable carmakers to bring new concepts of EVs almost relieving shortages perceived by customers. Driving range, loading capacity, speed and acceleration were formerly named as the main barriers of the utilization of EVs (Gärling and Thøgersen, 2001). These problems were mostly solved by using sophisticated methods of motor controlling, new lithium based batteries, and by decreasing total weight of vehicles, and they are no more limitative for the further market development. The most important benefit of EVs is high efficiency of electric engine (approx. $90 \%$ ), which enables to use less energy to travel the same distance as the ICVs (Horn, 2010). Considerable benefits are given by durable, clean and silent motors using no additional lubricants, which bring reduction of ecological and cost burdens (Horn, 2010). Moreover, EVs are not producers of carbon dioxide themselves, and therefore they are very suitable for operating in city centres.

\section{Barriers of Diffusion}

In the current market situation, we can observe barriers of EVs' mass utilization given by governments, carmakers (Chlebišová et al., 2010) and customers. The governmental efforts are mostly aimed to solve environmental problems generally or to support alternative sources of energy more than to support electric mobility in cities and thus support expansion of EVs. In the Czech Republic, owners of EVs do not have to pay road taxes and are favoured by deductions of damage liabilities, but the main problem is still insufficient recharging infrastructure. In this respect, charges for the transfer of ownership of obsolete high consuming ICVs or purchase advantages could be more supportive for the expansion of EVs. Nowadays, European countries are planning financial subventions to the green car sector of 5 milliard euro, and some of European countries are implementing plans of increasing electrification in the urban transport. Next problem is connected ith production of EVs. Carmakers were encouraged to produce most effective and economic ICVs supported by the environmental policy. High expenditures and investments on this research discourage firms to start with mass production of EVs under conditions of uncertainty. Also the lower demand for new EVs is not allowing carmakers to achieve economies of scale and therefore EVs are sold at a high price. Customers perceive the EV as new, unchecked, and have not enough information to be able to compare its advantages with classic ICVs and understand its 
customer benefits, which decelerate innovation adoption. The high price and insufficient infrastructure get customers to doubt about EV's purchase.

\section{Customers of Electric Vehicles}

The market penetration has to be conceptualized as a process starting with one small segment, and continuing with targeting most promising customers' segments to increase the market share. Marketing efforts have to provide strategy matching advantages, and limitation of EVs with potential customers' product requirements and transportation needs (Gärling and Thøgersen, 2001). The first stage of the marketing strategy is to determine and describe the segments and customers, and understand their purchase behaviour. Distinguishing purchase characteristics of particular customer segments, we can generally divide the potential customers into individuals and organisations (Chlebišová et al., 2010). Individual customers' purchase decisions are predisposed by individual socioeconomic characteristics in contrast with corporate customers' decisions which are more rational and, above all, are made by the group of individuals.

Our research is based on the presumption that requirements of corporate customers for company and executive cars are more compatible with current EVs' features. According to Gärling and Thøgersen (2001) company fleets are operated in working hours, in limited location, and mostly during the day in city traffic, and thus EVs are more compatible for usage in services or as company cars. The advantage of tax benefits and purchase benefits may be more interesting for business buyers who are price and cost sensitive. Also the possibility of utilization of EVs as a promotional tool within the green marketing strategy might be very attractive because ecological values are slowly bringing to the fore. A recent U.S. study found $28 \%$ of marketers believe green marketing increases visibility of the company more than other advertising. Thus the EVs might attract more potential customers, the more they value environment-friendliness (Gärling and Thøgersen, 2001). In chapter 5, these presumptions are discussed within the framework of marketing strategy, and the suitability of EVs offer to corporate customers is evaluated.

\section{$4 \quad$ Research methodology}

To explore entrepreneurs' attitude to EVs' utilization and buying behaviour of organisations in buying company and executive cars, the questionnaire research has been undertaken. The study has been focused on gathering the data across several sectors from entrepreneurs in Ostrava, and using the findings as a source for comparison of views in various entrepreneurships.

We developed the questionnaire with two main modules. The first module included questions following the general buying behaviour of organisations by company car purchase; the second module included the scales of attributes regarding the differences in buyers' perception between electric vehicles and vehicles with combustion engines. The attributes in the scales were derived from the study of Gärling and Thøgersen (2001) and from cooperation with the research team constructing an electric vehicle at the Technical University of Ostrava. These scales reflected the current barriers of EVs mass utilization, problem parameters of EVs in comparison with ICVs and expected barriers. Based on these, an online survey was developed using Google Documents tool.

The survey questionnaire consisted of a number of closed answers and statements regarding the attitudes of corporate customers to the issues of buying and utilization of EVs. The respondents were asked to evaluate their degree of agreement with each statement or to 
evaluate each attribute. In the scales, we used balanced four-point scale (e.g. strongly disagree - strongly agree, totally unimportant - totally important) supplemented with the possibility "I'm not able to answer" in several questions. Four points were used for better explanatory possibility and elimination of neutral answers. The samples of the respondents were derived from public company database www.firmy.cz, using the company sorting and search system. Using this possibility, a total sample of 1000 e-mail addresses was selected using criteria shown in Table 1. The sample was chosen in accordance with size structure of firms in Moravian-Silesian Region.

Table 1: Selection criteria

\begin{tabular}{|l|l|}
\hline Location of firm & Ostrava, Frýdek - Místek, Opava, Havírov \\
\hline Number of employees & $<9,10-49,50-249,250+$ \\
\hline Responsibility & general management, corporate buying, responsible for fleet \\
\hline Title & $\begin{array}{l}\text { Managing Director, Owner, Executive, Department Head, } \\
\text { Head of Fleet, Other }\end{array}$ \\
\hline
\end{tabular}

An e-mail message requesting participation in an academic study of the attitudes to the EVs was sent to each address in two phases in July and August 2010. At the bottom of each e-mail message there was the hyperlink, which took each potential respondent to the online survey. As an incentive to participate in research, an offer to obtain the results of the study after its completion was made. Since that survey was anonymous, the respondents were asked to indicate a contact email to gain these results.

Although only 86 respondents out of the initial distribution of 1000 participated in the survey $(8,6 \%)$, these response results are very good for an online survey. The characteristics of survey respondents are shown in the Table 2.

Table 2: Characteristics of the respondents

\begin{tabular}{|l|c|}
\hline Title & Share \\
\hline Owner & $61,0 \%$ \\
\hline Executive Director & $12,0 \%$ \\
\hline Department Head & $15,0 \%$ \\
\hline Head of Fleet & $7,0 \%$ \\
\hline Other & $5,0 \%$ \\
\hline Size of company & \\
\hline Micro firms (less than 9 employees) & $50,0 \%$ \\
\hline Small firms (10 - 49 employees) & $31,4 \%$ \\
\hline Medium firms (50 - 249 employees) & $12,8 \%$ \\
\hline Large firms (250 and more employees) & $5,8 \%$ \\
\hline End-users & \\
\hline Mainly customers & $17,0 \%$ \\
\hline Mainly businesses & $53,0 \%$ \\
\hline Equally both types & $30,0 \%$ \\
\hline Sector of industry/business & \\
\hline Business Services & $26,9 \%$ \\
\hline Car Services & $10,8 \%$ \\
\hline Manufacturing & $20,4 \%$ \\
\hline Servicing & $11,8 \%$ \\
\hline Building Industries & $8,6 \%$ \\
\hline
\end{tabular}


Table 2: Characteristics of the respondents (continued)

\begin{tabular}{|l|c|}
\hline Sector of industry/business & \\
\hline Transportation, Logistics & $6,5 \%$ \\
\hline Catering & $3,2 \%$ \\
\hline Others & $3,2 \%$ \\
\hline Company Headquarters & \\
\hline Office in Ostrava & $54 \%$ \\
\hline Office out of Ostrava & $46 \%$ \\
\hline
\end{tabular}

\section{$5 \quad$ Results and Discussion of the Findings}

The results of the research that regard utilization of company cars and general buying characteristics will be discussed first, followed by the attitudes and evaluation of the respondents towards the issues of utilization of EVs in firms.

\subsection{Characteristics of vehicles' utilization}

The fleets of the companies included 9 cars in average. The lowest value was 1 and the highest 100. Most firms in the region own three vehicles. The Pearson's ration value showed strong dependence between fleet and company size in terms of number of employee (Pearson Chi-Square 0,000). According to the expectation, the linear correlation showed that larger companies have larger vehicle fleets. Most operate upper and middle class vehicles - almost $40 \%$ of vehicles in fleets. $30 \%$ of vehicles operated in fleets belong to mini and lower class. Whereas currently available EVs belong to these two categories, in terms of size EVs are compatible with current fleet structure in the region.

Almost $50 \%$ of the companies own mostly vehicles with diesel engines, and $37 \%$ of companies own mostly vehicles with gasoline engines. $10 \%$ of companies operate vehicles with LPG engines and $3 \%$ vehicles with CNG engines. The only one firm $(0,7 \%)$ operates in its fleet also electric vehicle. An interesting finding is, that more than half of LPG $(57 \%)$ vehicles are operated in micro firms (firms with less than 10 employees). This could be explained by economic reasons, because LPG vehicle operation seems to be more economical. The diesel vehicles are operated mostly in companies engaged in services, business, consultant services, real estate $(29 \%)$ and in manufacturing $(25 \%)$. The LPG vehicles are mostly operated in taxi services and in driving schools. The structure of company fleet accordingly to the size of company is shown in Table 3 .

Table 3: Structure of fleets according to size of company

\begin{tabular}{|l|l|l|l|l|l|}
\hline Type of engine & Micro firms & Small firms & Medium firms & Large firms & Total \\
\hline Gasoline & $24,0 \%$ & $16,0 \%$ & $9,0 \%$ & $5,0 \%$ & $36,7 \%$ \\
\hline Diesel & $43,8 \%$ & $32,9 \%$ & $15,1 \%$ & $8,2 \%$ & $49,7 \%$ \\
\hline Hybrid & - & $100,0 \%$ & - & - & $0,7 \%$ \\
\hline LPG & $57,1 \%$ & $21,4 \%$ & $14,3 \%$ & $7,1 \%$ & $9,5 \%$ \\
\hline CNG & $25,0 \%$ & $25,0 \%$ & $25,0 \%$ & $25,0 \%$ & $2,7 \%$ \\
\hline Electric & - & $100,0 \%$ & - & - & $0,7 \%$ \\
\hline
\end{tabular}


The most imortant findings are connected with the conditions in which the vehicles are operated, that means operating during the day and type of traffic.

As explained above, electric vehicles are suitable mostly for city traffic, and they need time to be recharged. The current conceptions work with recharging during the night hours and recharging by battery replacement system. Also the range distances of EVs are still limited by the battery capacity, and therefore EVs are able to travel approximately $120-150 \mathrm{~km}$ for one recharging, which is compatible just for urban and shorter interurban traffic. The automobiles included in companies' fleets are used for various types of traffic. Most firms (56\%) use vehicles in interurban traffic, $40 \%$ vehicles are operated in urban traffic. Most of micro- (51 $\%)$, small- (63\%) and medium- $(63 \%)$ sized firms use vehicles in interurban traffic. Large companies differ - the most companies use vehicles in urban traffic $(67 \%)$. According to these findings, the EVs are more suitable for large companies.

Respondents were asked to identify intensity of usage of a company car for company purposes during the day. The possibility of using the company car for private purposes was not considered. The time period of vehicle operating is also very important in terms of recharging possibilities. The firms use vehicles in various time periods during the day, but the most companies use their vehicles 24 hours a day (47\%). $35 \%$ of firms use the vehicles anytime during the daytime and only $19 \%$ of firms use company cars in working hours. The firms using their vehicles only by the day will be able to recharge the batteries during the night, but for $47 \%$ of firms will be more suitable conception of battery replacement system, because vehicles' operating hours do not enable drivers to wait for recharging of batteries during the day. The time period of car operation during the day (see Table 4) is dependent on the industry of company (Pearson Chi-Square 0,003).

Table 4: Operation hours according to the sector

\begin{tabular}{|l|c|c|c|c|c|c|c|c|}
\hline \multicolumn{10}{|c|}{ Sector } \\
\hline Vehicles' operation hours & $\mathbf{1}$ & $\mathbf{2}$ & $\mathbf{3}$ & $\mathbf{4}$ & $\mathbf{5}$ & $\mathbf{6}$ & $\mathbf{7}$ & $\mathbf{8}$ \\
\hline Only in working hours & $43,8 \%$ & $0,0 \%$ & $18,8 \%$ & $18,8 \%$ & $6,3 \%$ & $0,0 \%$ & $0,0 \%$ & $12,5 \%$ \\
\hline Anytime during the daytime & $16,7 \%$ & $10,0 \%$ & $20,0 \%$ & $16,7 \%$ & $16,7 \%$ & $10,0 \%$ & $3,3 \%$ & $6,7 \%$ \\
\hline 24 hours a day & $32,5 \%$ & $17,5 \%$ & $25,0 \%$ & $7,5 \%$ & $5,0 \%$ & $7,5 \%$ & $2,5 \%$ & $2,5 \%$ \\
\hline
\end{tabular}

1 - Business Services, 2 - Car Services, 3 - Manufacturing, 4 - Servicing, 5 - Building Industry, 6 Transportation and Logistic Services, 7 - Catering, 8 - Other (Health Services, Publishing, Agriculture)

\subsection{Attitudes to EVs' Utilization}

The respondents were asked to evaluate the rate of agreement with statements reflecting characteristics of ICVs and EVs in two sets of questions. The first set was intended to evaluate statements regarding their attitudes to ICVs (see Table 5). Most of the respondents are well informed about characteristics of ICVs, and believe ICVs are reliable and with good service possibilities. On the other hand, the statements regarding environmental friendliness and economical features (price, costs and consumption) are evaluated more negatively.

In the next set of scales (see Table 6) the respondents evaluated the same statements according to their information and attitudes towards the EVs. More than $95 \%$ of the respondents are informed about the existence of EVs, which is positive, but it is apparent that the respondents have problems with qualifying particular characteristics of EVs. 
Table 5: Attitude to the ICVs

\begin{tabular}{|l|c|c|c|c|c|c|}
\hline \multicolumn{1}{|c|}{ Statement } & $\begin{array}{c}\text { Strongly } \\
\text { disagree } \\
(\mathbf{1})\end{array}$ & $\begin{array}{c}\text { Disagree } \\
\mathbf{( 2 )}\end{array}$ & $\begin{array}{c}\text { Agree } \\
\mathbf{( 3 )}\end{array}$ & $\begin{array}{c}\text { Strongly } \\
\text { agree } \\
\mathbf{( 4 )}\end{array}$ & $\begin{array}{c}\text { I'm not } \\
\text { able to } \\
\text { answer } \\
\mathbf{( 5 )}\end{array}$ & Average \\
\hline Vehicles are very reliable. & $2,3 \%$ & $12,6 \%$ & $52,9 \%$ & $25,3 \%$ & $6,9 \%$ & 3,1 \\
\hline Vehicles have low consumption. & $9,2 \%$ & $44,8 \%$ & $31,0 \%$ & $8,0 \%$ & $6,9 \%$ & 2,4 \\
\hline $\begin{array}{l}\text { Vehicles are produced by well known } \\
\text { carmakers. }\end{array}$ & $7,1 \%$ & $26,2 \%$ & $33,3 \%$ & $27,4 \%$ & $6,0 \%$ & 2,9 \\
\hline Vehicles look good. & $6,0 \%$ & $31,3 \%$ & $33,7 \%$ & $19,3 \%$ & $9,6 \%$ & 2,7 \\
\hline Vehicles have low prices. & $14,1 \%$ & $36,5 \%$ & $28,2 \%$ & $12,9 \%$ & $8,2 \%$ & 2,6 \\
\hline $\begin{array}{l}\text { Vehicles have low operation and } \\
\text { maintenance costs. }\end{array}$ & $10,6 \%$ & $40,0 \%$ & $30,6 \%$ & $9,4 \%$ & $9,4 \%$ & 2,4 \\
\hline $\begin{array}{l}\text { I have enough information about this } \\
\text { type of vehicle. }\end{array}$ & $0,0 \%$ & $19,3 \%$ & $45,8 \%$ & $26,5 \%$ & $8,4 \%$ & 3,1 \\
\hline Servicing is available. & $0,0 \%$ & $7,1 \%$ & $38,8 \%$ & $50,6 \%$ & $3,5 \%$ & 3,5 \\
\hline $\begin{array}{l}\text { These vehicles are environmentally } \\
\text { friendly. }\end{array}$ & $16,7 \%$ & $44,0 \%$ & $25,0 \%$ & $4,8 \%$ & $9,5 \%$ & 2,2 \\
\hline Vehicles have good references. & $1,2 \%$ & $23,5 \%$ & $52,9 \%$ & $10,6 \%$ & $11,8 \%$ & 2,8 \\
\hline
\end{tabular}

Table 6: Attitude to the EVs

\begin{tabular}{|l|c|c|c|c|c|c|}
\hline \multicolumn{1}{|c|}{ Statement } & $\begin{array}{c}\text { Strongly } \\
\text { disagree } \\
\mathbf{( 1 )}\end{array}$ & $\begin{array}{c}\text { Disagree } \\
\mathbf{( 2 )}\end{array}$ & $\begin{array}{c}\text { Agree } \\
\mathbf{( 3 )}\end{array}$ & $\begin{array}{c}\text { Strongly } \\
\text { agree } \\
\mathbf{( 4 )}\end{array}$ & $\begin{array}{c}\text { I' m } \\
\text { not } \\
\text { able to } \\
\text { answer } \\
\mathbf{( 5 )}\end{array}$ & Average \\
\hline Vehicles are very reliable. & $5,8 \%$ & $23,3 \%$ & $12,8 \%$ & $7,0 \%$ & $51,2 \%$ & 2,4 \\
\hline Vehicles have low consumption. & $3,5 \%$ & $16,3 \%$ & $17,4 \%$ & $33,7 \%$ & $29,1 \%$ & 3,2 \\
\hline $\begin{array}{l}\text { Vehicles are produced by well known } \\
\text { carmakers. }\end{array}$ & $7,0 \%$ & $20,9 \%$ & $24,4 \%$ & $14,0 \%$ & $33,7 \%$ & 2,7 \\
\hline Vehicles look good. & $4,8 \%$ & $34,5 \%$ & $21,4 \%$ & $9,5 \%$ & $29,8 \%$ & 2,5 \\
\hline Vehicles have low prices. & $43,5 \%$ & $24,7 \%$ & $5,9 \%$ & $3,5 \%$ & $22,4 \%$ & 1,6 \\
\hline $\begin{array}{l}\text { Vehicles have low operation and } \\
\text { maintenance costs. }\end{array}$ & $13,1 \%$ & $21,4 \%$ & $10,7 \%$ & $14,3 \%$ & $40,5 \%$ & 2,4 \\
\hline $\begin{array}{l}\text { I have enough information about this } \\
\text { type of vehicle. }\end{array}$ & $34,5 \%$ & $29,8 \%$ & $14,3 \%$ & $2,4 \%$ & $19,0 \%$ & 1,8 \\
\hline Servicing is available. & $26,2 \%$ & $19,0 \%$ & $8,3 \%$ & $1,2 \%$ & $45,2 \%$ & 1,7 \\
\hline $\begin{array}{l}\text { These vehicles are environmentally } \\
\text { friendly. }\end{array}$ & $4,7 \%$ & $7,1 \%$ & $23,5 \%$ & $50,6 \%$ & $14,1 \%$ & 3,4 \\
\hline Vehicles have good references. & $6,0 \%$ & $26,2 \%$ & $17,9 \%$ & $4,8 \%$ & $45,2 \%$ & 2,4 \\
\hline
\end{tabular}


More than $50 \%$ of customers are not able to answer if the EVs are reliable; almost half of the respondents cannot answer if the servicing is accessible, evaluate the references or maintenance costs. Approximately one third of the respondents cannot qualify consumption of EVs or their image and if they are produced by well-known carmakers. Also, almost one half of the respondents are not sufficiently informed about EVs. Only approximately 16,7 \% of the respondents have sufficient information to be able to evaluate the attitude towards EVs. According this, one of the significant problems is considerable lack of the information which has to be decreased before mass diffusion of EVs.

The respondents were able to evaluate the environmentally friendliness and consumption positively, but the prices were evaluated more negatively. Also more than one third of the respondents consider the EVs are not good-looking and have not good references, 29,1\% consider the EVs are not reliable.

The attitude toward utilization the EVs in fleets is most influenced by the statement that EVs are produced by well-known carmakers $(\mathrm{R}=-0,543)$. As shown in the research, the respondents are not able to evaluate many features of the EVs and therefore are influenced by the brand, which warrant function and quality of EVs, see Table 7.

Table 7: Correlation analysis

\begin{tabular}{|c|c|c|c|c|c|c|c|c|}
\hline \multirow{2}{*}{\multicolumn{2}{|c|}{ Model }} & \multicolumn{2}{|c|}{$\begin{array}{c}\text { Unstandardized } \\
\text { Coefficients } \\
\end{array}$} & \multirow{2}{*}{\begin{tabular}{|c|}
$\begin{array}{c}\text { Standardized } \\
\text { Coefficients }\end{array}$ \\
Beta
\end{tabular}} & \multirow[b]{2}{*}{$\mathbf{t}$} & \multirow[b]{2}{*}{ Sig. } & \multicolumn{2}{|c|}{$\begin{array}{c}\mathbf{9 5 , 0 \%} \text { Confidence } \\
\text { Interval for } \mathrm{B} \\
\end{array}$} \\
\hline & & B & Std. Error & & & & $\begin{array}{l}\text { Lower } \\
\text { Bound }\end{array}$ & $\begin{array}{l}\text { Upper } \\
\text { Bound }\end{array}$ \\
\hline \multirow[t]{11}{*}{1} & (Constant) & 3,145 & ,665 & & 4,733 &, 000 & 1,763 & 4,527 \\
\hline & $\begin{array}{l}\text { Vehicles are very } \\
\text { reliable. }\end{array}$ &, 187 &, 277 & ,201 & ,675 &, 507 &,- 389 &, 763 \\
\hline & $\begin{array}{l}\text { Vehicles have low } \\
\text { consumption. }\end{array}$ &,- 371 & ,207 &,- 434 & $-1,789$ &, 088 &,- 801 &, 060 \\
\hline & $\begin{array}{l}\text { Vehicles are produced by } \\
\text { well known carmakers. }\end{array}$ &,- 543 &, 187 &,- 584 & $-2,908$ &, 008 &,- 931 &,- 155 \\
\hline & Vehicles look good. &,- 228 & ,204 &,- 219 & $-1,116$ &, 277 &,- 653 & , 197 \\
\hline & $\begin{array}{l}\text { Vehicles have low } \\
\text { prices. }\end{array}$ & ,091 &, 244 & ,066 &, 372 &, 714 &,- 418 &, 599 \\
\hline & $\begin{array}{l}\text { Vehicles have low } \\
\text { operation and } \\
\text { maintenance costs. }\end{array}$ &, 358 &, 197 &, 512 & 1,818 &, 083 &,- 051 & ,767 \\
\hline & $\begin{array}{l}\text { I have enough } \\
\text { information about this } \\
\text { type of vehicle. }\end{array}$ &, 030 &, 180 & ,034 &, 165 &, 871 &,- 345 & ,404 \\
\hline & Servicing is available. & ,468 &, 267 & ,415 & 1,757 & ,093 &,- 086 & 1,023 \\
\hline & $\begin{array}{l}\text { These vehicles are } \\
\text { environmentally friendly. }\end{array}$ &, 306 &, 173 & ,372 & 1,775 & ,090 &,- 053 & ,665 \\
\hline & $\begin{array}{l}\text { Vehicles have good } \\
\text { references. }\end{array}$ &,- 157 &, 261 &,- 142 &,- 602 &, 554 &,- 699 & ,385 \\
\hline
\end{tabular}

a. Dependent Variable: What is your attitude toward utilization of electric vehicles in your company? 
The respondents were also asked to evaluate six statements regarding their attitude towards EVs, see Table 8. Using the factor analysis, the statements were regrouped into three categories: interest in electric vehicles, advantages and image of electric vehicles and charging.

\section{Interest in electric vehicles}

The possibility to test the EVs was very positively evaluated. According to the size of firm, agreed $51 \%$ of micro firms, $35 \%$ of medium firms and $80 \%$ of large firms. According to the sector, the most interested firms in this option will be the firms as follows: enterprising in manufacturing (67\%), car services $(63 \%)$, approximately $50 \%$ firms in building industries, logistic services and $30 \%$ of firms enterprising in servicing. If the respondents have more information, $47 \%$ of micro firms, $63 \%$ of small and $40 \%$ of medium firms would consider the purchase. According to the sector, most firms in services, manufacturing and building industries are interested in purchase of EV under the condition of being better informed. It follows that the respondents are not convinced that EVs are suitable enough for usage in company; approximately $40 \%$ answered positively and the same number negatively. The suitability for company usage is evaluated more positively by micro firms and small firms, while the informants from medium and large companies were more reserved in their answers. The EVs are suitable for $47 \%$ of firms in business services, for $40 \%$ of firms in building industry, $30 \%$ of transportation firms and $30 \%$ of firms providing servicing.

Table 8: Attitudes towards utilization of EVs

\begin{tabular}{|l|r|r|r|r|r|c|}
\hline \multicolumn{1}{|c|}{ Statement } & $\begin{array}{c}\text { Strongly } \\
\text { disagree } \\
\text { (1) }\end{array}$ & $\begin{array}{c}\text { Disagree } \\
\mathbf{( 2 )}\end{array}$ & $\begin{array}{c}\text { Agree } \\
\mathbf{( 3 )}\end{array}$ & $\begin{array}{c}\text { Strongly } \\
\text { agree } \\
\mathbf{( 4 )}\end{array}$ & $\begin{array}{c}\text { I'm not } \\
\text { able to } \\
\text { answer } \\
\mathbf{( 5 )}\end{array}$ & Average \\
\hline $\begin{array}{l}\text { Electric vehicle is suitable for our } \\
\text { usage. }\end{array}$ & $19,8 \%$ & $18,6 \%$ & $23,3 \%$ & $15,1 \%$ & $23,3 \%$ & 3,0 \\
\hline $\begin{array}{l}\text { Electric vehicles may improve our } \\
\text { image. }\end{array}$ & $19,8 \%$ & $20,9 \%$ & $20,9 \%$ & $20,9 \%$ & $17,4 \%$ & 3,0 \\
\hline We know where to charge. & $44,2 \%$ & $14,0 \%$ & $9,3 \%$ & $9,3 \%$ & $23,3 \%$ & 2,5 \\
\hline $\begin{array}{l}\text { We know about advantages of } \\
\text { electric vehicles. }\end{array}$ & $10,5 \%$ & $24,4 \%$ & $32,6 \%$ & $15,1 \%$ & $17,4 \%$ & 3,0 \\
\hline $\begin{array}{l}\text { If we have more information, we } \\
\text { would consider the purchase. }\end{array}$ & $21,2 \%$ & $20,0 \%$ & $28,2 \%$ & $16,5 \%$ & $14,1 \%$ & 2,8 \\
\hline $\begin{array}{l}\text { We would take the advantage of test } \\
\text { car lending. }\end{array}$ & $5,8 \%$ & $10,5 \%$ & $23,3 \%$ & $52,3 \%$ & $8,1 \%$ & 3,5 \\
\hline
\end{tabular}

\section{Advantages and image of electric vehicles}

The opinions of the statement „Electric vehicles may improve our image“ also differed $49 \%$ of the respondents answered negatively and $51 \%$ positively. The ANOVA analysis showed this factor was evaluated differently in various types of the firms (Sig. $=0,003)$. The rating of this statement statistically depends on the size of the company (Pearson Chi-Square $0,023)$; negative evaluation "strongly disagree" was found in more medium firms, in contrast with the large companies, whose representatives were convinced that electric vehicles may improve the firm's image. Up to $47 \%$ of manufacturing companies strongly agree with the statement, in contrast with $47 \%$ of the representatives of construction companies, who strongly disagree. Only one third of the respondents know about the advantages of EVs, which supports hesitance and low ability to evaluate the characteristics of EVs. 


\section{Charging}

Up to $44 \%$ of the respondents do not know where to recharge the EVs, and $23 \%$ of the respondents are not able to answer this question. Representatives of transport companies have more knowledge about EVs' recharging (only $20 \%$ of them don't know where to charge).

During the research, some important correlations were founded. The more information buyers have, the more suitable for their usage $(r=0,543) \mathrm{EV}$ is. The same situation occurs in the case of knowledge of advantages - the more knowledge about advantages the respondents have, the more suitable EVs are $(r=0,538)$. If the firms are informed about advantages of EVs, their attitude to the EVs as the promoting tool for image improvement is more positive $(\mathrm{r}=$ 0,546). If potential customers had more information, they would consider loaning of the test car $(r=0,578)$. All these correlations prove the quality and quantity of information as the key aspect of EVs diffusion to the fleets.

Our research proved that $67 \%$ of the respondents have positive attitude to the utilization of EVs; the average value was 2,9 on four-point scale. Also it was founded, that one third of the respondents from micro, medium and large firms have completely positive attitude to the utilization of EVs. The most positive answers were obtained from the servicing companies (64\%), construction companies (57\%), firms providing business services (44\%), and transport companies $(40 \%)$.

\section{Conclusion}

The research has showed that the motor type of vehicles is more important for purchase representatives of companies than the brand of the vehicle, but the well-known brand influences the purchase of EV in terms of credibility positively. Up to $67 \%$ of the firms prefer the diesel engine, therefore cars with economical diesel engines are the biggest competitor for cars with an electric engine. Approximately $40 \%$ of the companies use company cars in city traffic. This group of the firms represents the most potential customers for producers and sellers of electric cars in terms of current driving distances and charging technology of electric vehicles.

It is positive that already $95 \%$ of the respondents have heard about the existence of electric cars. The company representatives who participated in the survey, however, have great difficulty in assessing particular attributes of electric vehicles. More respondents than a half do not know whether electric cars are reliable or not, almost a half of the respondents do not know if the services are available, what references about electric vehicles dominate, or what the maintenance and operation costs are. For this reason, it is necessary to increase the awareness of corporate customers in the north Moravian region massively.

The attitude of the respondents towards the use of electric vehicles in their company is mostly influenced by the fact that electric vehicles are produced by well-known carmakers or brands. As the research has showed, the respondents are not able to evaluate many attributes of electric vehicles, and a brand is very important for them as a guarantee of quality and assurance. Using the correlation analysis, we have found that the bigger awareness of respondents will be, the more electric cars will be useful for activities of their companies. If they had more information about buying and using electric cars, they would use the possibility to borrow it in the test. As we have already mentioned, it is very necessary to raise the awareness of companies (customers). This awareness should be supported mostly by increasing public relations, publication of independent car tests, information brochures and 
free testing. Marketing communication campaigns should always contain brand of producer, which could increase perceived reliability and contribute to creating image of electric vehicle.

Up to $92 \%$ of the firms consider their low-cost maintenance, $91 \%$ low energy consumption, $93 \%$ of high life of the vehicle as the main criteria for the purchase of electric cars. These three advantages of electric vehicles should be strongly emphasized in the marketing campaigns. Government grants and tax relief would be welcomed up to $94 \%$ of the companies. Their introduction would significantly contribute to the expansion of electric vehicles.

\section{Acknowledgement}

The paper is supported by the SGS research project SP/2010106 „Využití klasických nástrojů marketingové komunikace pro podporu elektromobility v Ostravě“.

\section{Literature}

[1] GÄRLING, A.; THØGERSEN, J. Marketing of electric vehicles. Business Strategy and the Environment. 2001, vol. 10, no. 1, p. 53-65, ISSN 0964-4733.

[2] HORN, M. Roadmap to the Electric Car Economy. Futurist. 2010, vol. 44, no. 2, p. 40-45. ISSN 0016-3317.

[3] CHLEBIŠOVÁ, E.; KYZEKOVÁ, J.; SVOBODOVÁ, H. Marketing Study of the Electric Vehicles' Diffusion. In . Proceeding of the 11th Scientific Conference Electric Power Engineering, EPE'10. 2010. Brno : Vysoké učení technické v Brně. Ústav elektroenergetiky, 2010. ISBN 978-80-214-4094-4.

[4] WINDRUM, P.; CIARLI, T.; BIRCHENHALL, C. Consumer heterogeneity and the development of environmentally friendly technologies. Technological Forecasting and \& Social Change. 2009, vol. 76, p. 533 - 551. ISSN 0040-1625.

[5] XINLIAN, L. In the name of green. Bejing Review. 2009, vol. 52, no. 20, p. 32-33. ISSN 1000-9140.

\section{Classification JEL: M3}

\section{Ing. Eva Chlebišová, Ing. Jana Kyzeková}

Ph.D. studentky

Marketing and Business Department

Faculty of Economy

VŠB-Technical University of Ostrava

Sokolská 33, 70200 Ostrava

eva.chlebisova.st@vsb.cz 